\title{
Symbols of priority?
}

How the media selectively report on parties' election campaigns

\author{
Zachary Greene, Ph.D. \\ Chancellor's Fellow \\ University of Strathclyde \\ 16 Richmond St. \\ Glasgow G1 1XQ \\ Zacgreene@gmail.com \\ Maarja Lühiste, Ph.D. \\ Lecturer \\ Newcastle University \\ Newcastle NE1 7RU \\ United Kingdom \\ maarja.luhiste@ncl.ac.uk
}

\begin{abstract}
:
Leaders and MPs serve as the party's public face. Their image casts a shadow in which observers interpret policy statements. We hypothesize that media cover and voters understand policy messages through the lens of prominent party members' characteristics. Easy-to-observe descriptive traits, such as gender or ethnicity, cue parties' policy priorities. Media are more likely to emphasize party messages on issues historically related to these groups when they are visible in the party's public image. We test hypotheses from our theory using data on prominent party members' descriptive characteristics, policy statements, and media coverage of statements from the European Election Studies. Data from the 1999, 2004 and 2009 European elections evidence support for our theory. Parties with more female representatives signal stronger emphasis on gendered issues in media reports. The results hold implications for our understanding of the ways in which parties deliver and voters receive campaign messages. This research offers an explanation for voters' limited knowledge of parties' policy positions; media reinforce existing gender stereotypes and voters' pre-dispositions by selectively reporting policy statements.
\end{abstract}

Key words: Manifestos, Media Coverage, Issue Diversity, Elections, Parties, Gender. 
Electronic and traditional media play a key role in shaping the success of parties' election campaigns. In a context of declining partisan attachments (Kölln 2014) and increasingly media centered campaigns (Semetko et al. 2013; Banducci et al. 2015), it is difficult to overestimate the importance of media coverage in electoral contests. Without attention from the media, parties' electoral messages will struggle to be heard beyond their most ardent supporters. While the media rarely design coverage around the issues most salient to parties (Kostadinova 2015), parties' press releases often make the news (Hopmann et al. 2012; Haselmayer et al. 2015; Helfer and van Aelst 2016). When news media emphasize issues, however, it can have profound impacts on the success for even small or relatively extreme parties. Television and newspaper reports, for example, provided key support to the rise of the antiimmigrant Vlaams Blok in Belgium (e.g. Walgrave and de Swert 2004). While research makes clear that the media have a range of effects on the electoral and policy-making process, the dynamic process through which it interacts with parties' messages is less developed. Parties' agency is often unaccounted for. Do these reports emphasize the substance of parties' messages or focus on parties' broader characteristics?

While past research offers valuable insights to individual candidates' media portrayals (Goldenberg and Traugott 1987; Heldman et al. 2005; Kahn and Goldenberg 1991; Kittilson and Fridkin 2008; Lühiste and Banducci 2016), less evidence explains the way that the media balance attention to parties' policy statements and the parties' public image more generally. Although parties might emphasize policy on a range of topics, reporters must balance these statements with evidence from the parties' broader characteristics to determine parties' more sincere, underlying goals. Take, for example, Fine Gael in the 2004 EP elections. Fine Gael dedicated nearly 19 percent of their EU manifesto to issues historically important to women such as welfare state issues, but showed little symbolic commitment; men largely occupied the leadership and parliamentary delegation (women constituted only $6 \%$ of the party's MPs). Consequently, media reports largely ignored their attention to these issues. Do campaign statements appear opportunistic and electorally motivated, or do the priorities of the party's leadership and parliamentary delegation appear consistent with these goals? We propose that television and news reports on parties' campaigns reflect not only the substance of parties' messages, but also evaluate those claims in light of the party's most visible public face, the parliamentary delegation and leadership. ${ }^{1}$

As a test case, we consider media's attention through the lens of research on traditionally under-represented groups and women's representation. Media reports often address representation of women in their post-election summaries, but it is less clear how news reports use women's presence as members of parliament and in the party's leadership to evaluate the credibility of parties' claims. Gender likely acts as

\footnotetext{
${ }^{1}$ We would like to thank Michael Courtney (Dublin City University) and Thomas Meyer (University of Vienna) for their comments on earlier drafts of this manuscript.
} 
a useful heuristic for journalists as parties with greater representation are more likely to emphasize a range of issues in their electoral campaigns (Kittilson 2003; Greene and $\mathrm{O}^{\prime}$ Brien 2016) and are potentially more likely to debate and pursue those policies upon entering office (Bäck et al. 2014). Linking research on women's representation and intra-party politics to the media's gaze, we propose that parties' messages will be most effective at converting the issues in their platforms to media attention when the composition of the party's leadership and parliamentary delegation signal that the party will credibly dedicate attention to those issues in office. More simply, the media will report on parties' attention to issues historically linked to women's representation more when the party's MPs and leadership contains a stronger female presence.

To examine hypotheses from this perspective, we use data on the content of parties' election platforms and the gender of the parties' leadership and parliamentary delegations. We use these data to predict the relative attention news reports give to parties' European election campaigns using data on media coverage from the 1999, 2004 and 2009 European Election Studies. ${ }^{2}$ These data allow us to isolate the topic of each media report as well as specific references to parties and party actors. Given the relatively low information environment on European elections, we argue that these data present a conservative case for the responsiveness of media coverage to parties' election campaigns. Results from this analysis demonstrate that the media respond more to parties' appeals on issues historically associated with women's representation when parties' national parliamentary delegations and leadership signal a strong symbolic commitment to those issues.

The results hold broad implications for theories of representation and our understanding of democratic governance. Television and newspapers' attention to issues is important to the study of the representation of traditionally under-served groups, the success of election campaigns, and our conceptions of democratic representation more broadly. From the perspective of electoral campaigns and policy representation, media attention influences the success of parties (Walgrave and de Swert 2004). Furthermore, as Walgrave et al. (2007) show, the media have substantive impacts on both the parliament and governing cabinet's policy focus. The exact policy impact may, however, depend on whom the media can cover. Parties with more descriptively diverse political elites send a stronger signal to the newsroom to diversify its coverage of campaigns and politics. This, in turn, provides

\footnotetext{
${ }^{2}$ In a working paper, we extend the analysis to the 2014 European Parliament elections by performing automated content analysis of media reports (Greene and Lühiste 2017). We find evidence consistent with the analysis presented using data from the Ireland, the Netherlands and the United Kingdom. For additional information, see the author's website: http://www.zacgreene.com.
} 
a pathway for more meaningful substantive impacts of increased diversity, as media may use the symbols of representation to cover more and different topics and thereby encourage real policy change. More broadly, by seeking to understand the ways that citizens receive parties' messages, this research helps to evaluate the success and ability of citizens to be informed about party competition in a range of electoral environments (Banducci et al. 2015). Further information on media's conditioning role broadly adds to mounting evidence of the ways in which democratic representation and politics differs for female and male political leaders (Krook and O'Brien 2012; O’Brien et al. 2015; O’Brien 2015; Lühiste and Kenny 2016).

\section{MEDIA COVERAGE AND ELECTION CAMPAIGNS}

Media coverage of election campaigns acts as the mechanism through which parties inform and persuade voters about their programmatic stances. Without coverage, parties only have limited tools to extend their messages beyond activists and members. The media, therefore, plays a crucial role in election campaigns.

Research on media coverage explains that the media act as a mobilizing agent, promoting civic engagement and participation (Norris 2000; Freedman et al. 2004). Hallin and Mancini (2004) consider partisan press, in particular, to reinforce readers' ideological predispositions by strengthening the bonds between parties and citizens. This reinforcement should not only motivate citizens to go to the ballot box, but also make their vote choice more informed. Indeed, past research offer empirical evidence that newspaper readership promotes citizens' political knowledge and engagement (Luskin 1990; Gordon and Segura 1997). This evidence contrasts more cynical perspectives, such as the "media malaise" hypothesis, which claims the mass media to generate political disillusionment, cynicism, and alienation (Robinson 1976; Newton 1999).

Focused more directly on the relationship between campaigns and media attention, studies offer a number of explanations for how the issues newspapers and television address influence the electoral contests. Through priming and agenda setting effects, ${ }^{3}$ the media lead voters to consider some issues as more important than others by featuring these issues more in news reports (Weaver 1981; Iyengar and Kinder 1987; West 2001). Because they are set on the agenda, specific issues will be primed in the minds of citizens, leading the electorate to give those issues more weight when deciding their vote (Iyengar and Kinder 1987). This approach suggests that journalists are not passive conduits of political information. Journalists' values,

\footnotetext{
${ }^{3}$ We refer to agenda setting as the extent to which media outlets decide what issues and stories to cover, and how to cover them (Traudt 2005).
} 
at least in part, affect the story selection and the lens through which they present political news (Altheide and Snow 1979; 1991). Furthermore, some research indicates that mass media not only affect electoral contests but also broadly exert influence on government policies. For example, the issues addressed by mass media in Belgium largely dictate the policies addressed in parliament and to a less extent the governing cabinet's priorities (Walgrave et al. 2007). The type of media outlet also determines its impact; newspapers are often give more in depth coverage and analysis than television reports (Protess et al. 1987; Schoenbach 1991; Bartels 1996; Eilders 1997; Banducci et al. 2015), although their influence varies (Trumbo 1995; Kleinnijenhuis 2003). Unlike more traditional forms of media, research on new, social media finds less extensive effects on government policy attention (Williams and Delli Carpini 2011).

While the news media can be a powerful actor, media agendas are not solely determined by journalists or news organizations (Semetko et al. 2013). Media portrayals of parties' electoral campaigns are likely influenced by the parties themselves. Scholars find, for example, that media cover parties' press releases in Denmark (Hopmann et al. 2012) and Austria (Haselmayer et al. 2015). Through a set of experiments, Helfer and van Aelst (2016) find that journalists in Switzerland and the Netherlands are more likely to report on press releases when they are unexpected or indicate important policy news, yet political factors like government status play an important role in the Netherlands. In addition, journalists in Germany, France, and the United Kingdom consider parliamentary questions on issues the media had previously paid attention to and questions from opposition more newsworthy than those on novel topics or from the government (Santen et al. 2013).

Further, conditions such as the economy or external shocks that influence media coverage also relate to the most important issues that parties emphasize in their electoral campaigns and that lead to government policies (e.g. Bevan and Greene 2016, 2017). Parties direct voters' and news reporters' attention to certain policy areas by increasing focus on those issues in their campaigns (Vavreck 2009; Hellwig 2012; Semetko et al. 2013; Greene 2015; Williams et al. 2016). We extend this research by arguing that parties' media coverage also depends on their perceived issue competence or credibility.

The valence politics perspective suggests a link between parties' issue ownership and respective media coverage. Parties' perceived competencies vary across policy areas and electoral contexts (e.g. Bélanger and Meguid 2008; Geys 2012). Parties from historically left families have been shown to enjoy greater media coverage on valence issues, such as employment and health care, while conservative parties are more likely to be featured in stories focusing on economic growth, taxation, and crime reduction (Hayes 2008; Kleinnijenhuis and Pennings 2001). 
Parties also politicize owned issues according to their position in the opposition or government to influence perceptions of the government's competence (Thesen 2013). Like parties, individual politicians' perceived competence varies across issues. Past research on voter stereotypes has found, for example, that male candidates are perceived as better able to handle the economy, the military, foreign affairs and crime, while female candidates are stereotyped as more adept at dealing with education and social welfare issues (Huddy and Terkildsen 1993; Koch 2002; King and Matland 2003; Lawless 2004).

The question that arises is whether a party lacking perceived issue competence on certain policy areas could potentially poise its media coverage by diversifying its public image in terms of the characteristics of the most prominent party members? How exactly the issues put forward by parties in their campaign messages interact with gender stereotypes in shaping their news media coverage is yet to be explored.

\section{ELECTION CAMPAIGNS AND WOMEN'S REPRESENTATION}

Parties' organizational characteristics and policy messages are important predictors of electoral success. Studies of election campaigns suggest that parties use policy statements to attract support. Research from this perspective argues that parties compensate for declining partisan attachments by fielding increasingly media centered campaigns (Norris 2000; Semetko et al. 2013). But, how does the descriptive make-up of parties' public images influence campaign messages and subsequent news media attention? Should we expect the issues the media associates with a party to be affected by the prominence of its female members?

Research examining news media reports of electoral campaigns offers a mixed record of evidence with regards to the amount of coverage male and female candidates receive. While some studies show women to gain less news media attention than men (Gidengil and Everitt 2000; Heldman et al. 2005; Meeks 2012; Ross et al. 2013; Lühiste and Banducci 2016), other scholars find no gender differences in the amount of coverage (Smith 1997; Bystrom et al. 2001; Kittilson and Fridkin 2008). On the contrary, surprisingly little debate considers the gendered nature of issue coverage.

Past research consistently shows that stories featuring women are different from stories focusing on male candidates (Bystrom et al. 2001; Kittilson and Fridkin 2008; Conroy et al. 2015). For example, research examining associations between gender and issue attention suggests that women's presence may increase, or at least shift, the attention to varying issues. News stories featuring female candidates are more likely to focus on so-called compassion issues, such as social welfare, 
education, and health care (Smith 1997), while male candidates are more often covered in stories that discuss the economy (Smith 1997; Bystrom et al. 2001). Hence, women, in comparison to men, are not only likely to bring different topics to the public agenda, but also influence the specific topics news stories associate with the party. For example, journalists' gender stereotypes may lead reporters to focus more on the so-called "compassion issues" when the party presents the media with more women to cover. ${ }^{4}$

Our perspective fits well with the logic of media reports. This research indicates that news media may focus more on issues deemed more likely to attract and maintain audience interest (Zaller 1999), and the decision to cover (or not cover) certain issues can also be influenced by who delivers the message and whether the journalists consider the messenger competent and salient in the eyes of the news consumer. As a signal of diversity, women MPs and leaders could act as a strong symbol that can be taken as a heuristic for journalists that the party will act on these issues. Essentially, their campaign messages on compassion based issues become more credible. Likewise, women legislators may encourage the media's reliance on these heuristics as they are more likely to focus on compassion issues in campaigns (Dabelko and Herrnson 1997) and in the legislature (Burrell 1998; Swers 2002; Dodson 2006). Furthermore, male candidates have been found to focus more on "female" issues in their campaigns when competing against women (Kahn 1994; Fox 1997; Dolan 1998; Atkeson and Krebs 2008). Thus, increased gender equity among prominent party members is likely to increase the broader salience of compassion based issues in new stories. Therefore, we hypothesize that the more women a party has in its parliamentary delegation, the more often the party is featured in news stories covering compassion issues relative to the issues in their manifesto (H1).

We expect female party leadership to have a similar impact on parties' news topic coverage as the increased share of women MPs. Female leaders are likely to campaign on a broad set of issues to attract votes (Greene and O'Brien 2016), much like parties with a greater number of female MPs. This attention likely carries over to their broader political campaigns, in the legislature, or in government. Moreover, following the logic of valence politics, female leaders in particular should try to capitalize on issues, such as education, health care and social welfare, to increase their perceived competence.

Furthermore, the media are likely to rely more strongly on the leader's gender as a cue for the party's goals. Substantial evidence indicates that party leaders have become more prominent in election campaigns across Europe (e.g. Farrell and Webb 2006). Likewise, party leaders' perceived competence and popularity heavily

\footnotetext{
${ }^{4}$ We refer to compassion issues as those issues historically linked with women's representation (e.g. social welfare, education, health care, gender equality and women's issues).
} 
impacts voters' choice of parties (Evans and Andersen 2005) and even the likelihood that voters perceive party change (e.g. Somer-Topcu 2016). Consequently, female leaders should emphasize the issues that they enjoy higher levels of perceived competence with voters. Combined with the journalists' use of shortcuts, gender stereotypes and easily identifiable symbols to identify competence and credibility, these trends will shift the parties' issue coverage towards compassion issues. We thus hypothesize that parties with a female leader, as opposed to parties with a male leader, are more often featured in news stories focusing on the compassion issues (H2).

We add that it is unlikely that greater attention to compassion issues by increased women's presence in parliament would come at the expense of previously covered issues. Therefore, as the increased presence of women introduces alternate topics to the campaign, a more diverse public profile of a party is likely to diversify its issue coverage in the media as well. Indeed, recent scholarship offers empirical evidence that the total number of issues parties cover in their election manifestos increases as the share of women in their parliamentary delegation rises (Greene and O'Brien 2016). We theorize that because the news room relies, at least to a certain extent, on parties' campaign messages while covering elections, this increased issue diversity likely carries over to the media attention parties receive. Research on the press coverage of U.S. mayoral candidates provides further support for this expectation; the presence of female mayoral candidates lead the media to expand the issues covered in local newspapers (Atkeson and Krebs 2008). We propose that the presence of women acts as a cue to reporters that these issues are more important to the party, even more so than the issues they include in their platforms. Put simply, we predict that the more diverse is the party's public image, the more diverse issues the media associates with it. This logic leads us to hypothesize that the news media associates a party with more issues as women take on more prominent roles (such as MPs) in the party (H3).

An alternate logic likely explains coverage for the most prominent roles within parties. We propose that female party leadership is likely to have a smaller effect. Two perspectives, focused on the most important person representing the parties' image, predict that parties with a female leader would drive the media to report on fewer issues than those included in their campaigns.

First, we argue that the presence of a female leader focuses the media's attention to only historical women's issues. In the case of a high number of female MPs, which indicate gender diversity within the party, the media draws attention to issues historically associated with both men and women as the presence of female MPs increases. Indeed, this effect might reverse (reflecting a parabolic relationship) if a party becomes dominated by female MPs. This logic further implies that although the media may shift the attention to a new set of issues with a female leader, these issues are likely to supplant, rather than be added to previous issues. Female 
leadership, due to its singular prominence within the party, does not necessarily signal greater diversity. For example, the German Christian Democratic Union's delegation has, until today, remained less gender balanced than the parliamentary fractions of their primary competitors, the Social Democratic Party and the Free Democratic Party, despite being led by Angela Merkel since 2000. As the persona of a leader is likely to have a greater impact on the party's overall message and that message needs to be associated with the leader, the presence of a female leader is unlikely to signal a broad range of issues, but instead, narrowly focus on the issues most important to that leader. The issues associated with a new leader supplant those of the older leadership (see, for example, Somer-Topcu 2016). This implies that the issues the leader emphasizes change, but this difference does not add to the overall diversity.

Furthermore, a second logic predicts a decreased range of issue attention for parties with female leaders based on the media's broader treatment of female politicians. News stories covering the most prominent female candidates tend to pay more attention on women's appearance, personal lives, and personality traits than on policy issues (Dunway et al. 2013; Kahn 1994; 1996; Woodall and Fridkin 2003). This implies that a party led by a woman may receive less issue-based media coverage than a party with a male leader.

This discussion implies that the issue priorities female leaders hold and the media's stereotypes both point towards a narrower policy image. While more female MPs indicate an expanded set of issue priorities, having the most prominent party member as a woman could result in journalists focusing less on the party's policy program. Instead, reports focus predominantly on a limited set of issues and more on the traits and the personality of its leader. As a result, we hypothesize that a female party leader, as opposed to a male leader, does not increase the number of issues the party is associated with in the news media, even if the issue diversity in the party's election manifesto is high (H4).

In summary, we argue that the increased presence of women in parties' parliamentary delegation and leadership will impact the relative diversity and attention to issues that media reports associate with them in elections. More female MPs increases issue diversity as journalists discuss these new issues in tandem with issues also linked to male MPs. Media reports decrease the diversity in the face of a female party leader, as they shift predominately to compassion based issues. In both cases, this leads us to predict greater media attention connecting parties to historical women's issues or compassion based issues, although the presence of a female leader will have a more dramatic effect. If media reports also base their coverage on parties' actual statements, then these effects should only matter relative to the diversity and issue attention in parties' election campaigns. In the next section, we outline our empirical strategy for examining these hypotheses. 


\section{DATA AND METHODS}

To test our primary hypotheses we combine data on the media's issue attention, parties' manifestos, and parties' parliamentary delegations. In particular, we focus on reports in the media related to elections to the European Parliament in 1999, 2004 and 2009. ${ }^{5}$ European Parliament elections provide us with the opportunity to test hypotheses in an unlikely scenario for coverage of parties' election platforms. European elections, often held low salience with voters, create a low information environment. Further, media reports rarely directly cite party actors. Due to the low salience of these elections, media should be more likely to form their reports from national politics and government figures rather than parties' European manifestos. Because the same candidates and parties often compete in both national and European elections (Reif and Schmitt 1980; Franklin 2006), and voters rely on national level media outlets, it is likely that the national political climate dictates the news coverage around European elections. Any evidence that media campaigns filter these through national symbols such as parties' parliamentary delegations would be strong support for our approach. Moreover, research suggests that gender cues and stereotypes affecting voting behavior are especially prevalent in low information contests (Plutzer and Zipp 1996; McDermott 1997; Dolan 1998). Finally, European Parliamentary elections are the only context in which comparative media content data of multiple election cycles are available at this point to examine the effects parties' issue attention and public profile have on campaign coverage.

Therefore, using the European Election Study Media Content Analysis (1999; $2004 ; 2009),{ }^{6}$ we find the percentage of reports that directly reference parties as well

\footnotetext{
${ }^{5}$ We include parties from Austria, Belgium, Czech Republic, Denmark, Estonia, Germany, Greece, Ireland, Italy, Luxembourg, the Netherlands, Portugal, Slovakia, Spain, Sweden, United Kingdom. ${ }^{6}$ Both newspapers and television news coverage were coded in each country in each election year. The sample includes at least two television news outlets (public and commercial) and at least three newspapers (two "quality" and one tabloid) per country. For television the most widely-watched public and commercial television newscast in each country were coded. For newspapers one rightwing and one left-wing broadsheet paper and one tabloid paper in each country were coded. The content analysis was conducted for news items published or broadcast within three weeks running
} 
as the primary issue the report addresses out of ten possible categories. For example, a report that discusses comments on inflation or unemployment by members of the Christian Democratic Union would be classified as media attention to economic policy for the party. We then find the percentage of all media statements related to each issue for each party and use these categories to construct the Effective Number of Media Issues (M-ENI) and the number of statements classified as "compassion issues."

Following Greene (2015; see also Boydstun et al. 2014; Greene and O’Brien 2016; van Heck 2016), we first convert the statements for each issue into percentages, using the total number of statements for that party in an election year as the denominator. We then transform these percentages to measures of entropy using Shannons' H. Following Jost (2006), we convert Shannon's entropy into the Effective Number of Issues. ${ }^{7}$ For media reports, the measure theoretically ranges from one to ten, but in practice only reaches 8.8. As we show in Figure 1, the distribution of MENI skews towards one with a mean of 2.75 and a standard deviation of 1.3. $<<<$ Figure 1 Here $>>>$

Our primary hypotheses predict that parties' national characteristics moderate European manifesto diversity. Party leaders' gender and the distribution of their parliamentary delegations determine media coverage of parties' European manifestos. Therefore, we use the European Parliamentary Election Study Euromanifesto component (EES 2009; Braun et al. 2010) to construct the Effective Number of Manifesto Issues in the EP elections (ENMI-EU) for each party following the same procedure used to transform media attention. ${ }^{8}$ The total range of topics coded by the Euromanifesto project is greater than those for the longitudinal media

up to the election. With regard to story selection, for television all news items were coded; and for newspapers, all news items on the title page and on one randomly selected page as well as all stories pertaining particularly to the EU and/or the EU election on any other page of the newspaper were coded (within Political/News, Editorial/Opinion/Comment, and Business/Economy sections) (Schuck et al. 2011). Ultimately, this case selection covers nearly all campaign-related news stories in major news outlets in each member state.

${ }^{7}$ For a more technical explanation or the media categories, see the Appendix.

8 To improve the comparability of the measures, we collapse any subcategories into their parent category and collapse the categories identifying what level the issue is focused on (National or EU) to a single issue code. 
dataset, ${ }^{9}$ leading the ENMI-EU to range from one to just over 27 with a mean of 8.89 and standard deviation of 7.4. Intriguingly, the ENMI-EU is somewhat bimodal with the mean ENMI-EU increasing dramatically from 4.7 in 2004 to 15.2 in 2009, perhaps reflecting the increasing importance of the European Parliament. Whereas issues related to the military, for example, are regularly discussed in the each election, other topics such as the competencies of the European Parliament and Commission only become subject of manifestos in 2009.

Building on Greene and O'Brien (2016), we exploit a new data set on the gender of the party leadership and the percentage of women MPs in each party's parliamentary delegation at the national level. ${ }^{10}$ For both variables, we use the values from the outcome of the last parliamentary election before European elections in that country. ${ }^{11}$ We include interactions of these variables with the party's ENMIEU to predict media attention to the parties.

We also include some control variables to account for additional information about parties' strategies and national electoral success from the Comparative Manifesto Project (CMP) (Volkens et al. 2015). In addition to our primary independent variable constructed from European manifestos, we include the national party's Effective Number of Manifesto Issues (ENMI-Nat) to account for media attention that might result from recent national elections. We also measure parties' relative extremism using the party's absolute distance from the mean manifesto position based on Lowe et al.'s (2011) transformation of the CMP left-right scale. To account for parties' past electoral success, we use the party's percentage vote in the last national election. Presumably more electorally successful parties will gain greater media attention across issues than smaller parties. Finally, we control for whether the party has adopted voluntary quotas or if there is a legislative quota (quota law) for the EP elections. Past research suggests that countries and parties that have adopted candidate gender quotas directly signal commitment to increasing

\footnotetext{
${ }^{9}$ See the Appendix for detailed information on how we linked issue categories in the EES Media Studies to those in the Euromanifesto Project.

${ }^{10}$ We supplemented this data with information on the leadership and parliamentary delegations in Estonia.

${ }^{11}$ We use the share of women MPs a party has at the national legislature to measure the level of gender diversity in the party's public image because the media coverage of European elections is largely focused on national politics. Therefore, the party's national parliamentary delegation is likely to cue the newsroom about the parties' perceived dedication to and competence of issues traditionally related to women.
} 
women's representation, which may encourage or prime the media to pay more attention to compassion based issues.

Our unit of analysis is the media attention related to European Parliamentary election in 1999, 2004 and 2009. For estimating the issue salience of compassion issues ( $\mathrm{H} 1$ and $\mathrm{H} 2)$, we predict the number of statements on compassion issues using a Negative Binomial Regression Model with party level random effects. ${ }^{12}$ For estimating the diversity of issues a party is associated with in media reports ( $\mathrm{H} 3$ and H4), we predict the Effective Number of Media Issues (M-ENI) using an OLS Regression Model. To account for the recurrence of the same parties across years, we include fixed effects at the party level. ${ }^{13}$ Robust standard errors are in parentheses.

\section{ANALYSIS}

\section{Issue salience and compassion issues}

In our first hypotheses ( $\mathrm{H} 1$ and $\mathrm{H} 2)$, we predict that the media will connect a party more to compassion issues - relative to their manifestos - when it has more female MPs in the national parliament. We test these hypotheses by predicting a count of the number of articles on compassion issues; those classified by the EES data as historically women's issues, minority issues, education, and social issues. As we show in Figure 2, the distribution of attention to compassion issues skews left. Therefore, we use a negative binomial regression model with random effects at the party level. We include an interaction of parties' attention to the same issues in their EP manifestos with the percentage female MPs and whether they have a female party leader to test our hypotheses. The results indicate nuanced support for the theory. $<<<$ Figure 2 Here $>>>$

In our first hypothesis (H1), we predict that the media will address more issues traditionally related to women's representation when the party's national delegation includes a greater proportion female MPs. The results in Table 1 are consistent with this proposition. The coefficients for the constitutive terms for percentage female MPs are positive in both models and statistically significant in the Full Model. In the context in which parties do not discuss these issues in their EP manifestos, higher percentages of female MPs increases the expected number of media references to these issues. Interestingly, the coefficient for the interaction of

\footnotetext{
12 Models using fixed effects fail to converge.

13 Analyses using random effects for the party and year lead to substantively similar results.
} 
issue salience in parties' EU manifestos and the percentage female MPs is negative and significant in the Full Model.

\section{$<<<$ Table 1 Here $>>>$}

We demonstrate the predicted effect of female MPs on the number of media reports in Figure 3. The predicted effects tell a story consistent with the hypotheses. At low levels of salience for compassion issues, parties with more female MPs increase the expected number of media reports. For parties discussing these issues in some detail the presence of more female MPs does not have any meaningful additional effect over addressing the issues in their platforms. The predicted effects from Figure 3 imply that for parties with higher levels of female MPs, the media connects the parties to compassion issues regardless of the attention they give to those issues in their manifestos.

$<<<$ Figure 3 Here $>>>$

Following these results, Table 1 provides weak evidence consistent with our second hypothesis (H2). We predict female party leaders will lead the media to emphasize compassion based issues more strongly than their manifestos would predict. The signs on the coefficients for female party leaders and parties' attention to these issues in their EU manifestos switches between the Simple and Full models in Table 1, indicating that controls, such as the parties' left-right ideology and the total attention female party leaders receive, likely plays an important role in the way that media represents female party leaders.

We demonstrate graphically the effect of increased party attention to compassion based issues for male and female leaders in Figure 4. Intriguingly, the large coefficient for the interaction of issue salience and having a female leader in Model 2 dramatically increases the expected number of media reports on these issues as the second hypothesis predicts, yet the coefficients are not jointly significant from zero at conventional levels as the confidence intervals demonstrate. $<<<$ Figure 4 Here $>>>$

\section{Issue diversity}

In our third hypothesis (H3), we predict that the media will report on more issues relative to parties' manifestos when they have more female MPs in the national parliamentary delegations. We test this hypothesis by predicting the Effective Number of Media Issues (M-ENI) using the interaction of Effective Number of Manifesto issues in Euromanifestos (ENMI-EU) with the natural log of the percentage of women in parties' parliamentary delegations. The results in Table 2 support the hypothesis. Consistent with the theory, the coefficient representing the interaction is negative and statistically significant at the $95 \%$ confidence level in the 
simple model and the full model. The constitutive term for ENMI-EU is also negative and weakly significant. The coefficient for the percentage female MPs is positive, statistically different from zero at the $95 \%$ level.

$<<<$ Table 2 Here $>>>$

To demonstrate the effect of the variables, we predict the marginal effect of ENMI-EU at low and high values (one standard deviation above and below the mean) as the percentage of female MPs increases in Figure 5. The effect is clearest for parties with low ENMI-EU, as parties with only a smaller percentage of female MPs associated with decreased diversity of media issues (M-ENI). The marginal effect reverses for parties with a greater proportion of female MPs. M-ENI increases as parties have more female MPs. This effect disappears and nearly reverses for parties with higher levels of ENMI-EU, although the interaction is not statistically significant at these higher values.

$<<<$ Figure 5 Here $>>>$

In our final hypothesis (H4), we predict that the presence of a female party leader causes the media to decrease M-ENI, as the media primarily attends to issues historically related to women's issues. Like the results from the third hypothesis, the estimates are consistent with our primary expectations. The coefficient for the interaction of female leadership with ENMI-EU is negative and statistically significant at the 95\% level in the full model.

We demonstrate the marginal effect of having a female party leader over values of parties' ENMI-EU in Figure 6. Indeed, as we predict in H4, the marginal effect of discussing more issues associates media focus on fewer issues for female leaders. The effect reaches statistically significant differences from parties with male leaders at the $95 \%$ level in the full model. ${ }^{14}$

$<<<$ Figure 6 Here $>>>$

Together, the results demonstrate support for our second set of hypotheses. Parties with few female MPs and low diversity messages lead the media to underreport on issues in their platforms, but the media reports on more issues when the percentage of female MPs increases. The media decreases the diversity of issues relative to parties' manifestos when they have female leaders, yet the effect is only subtly smaller than for parties with male leaders. Underlying these changes to the diversity in media reports is the contention that the media uses MP and leader gender as a symbol or heuristic about the party's policy goals. This would mean that

\footnotetext{
${ }^{14}$ A Wald test of the joint significance for the interaction of female party leaders and ENMI-EU indicates that the combined effect is statistically different from the coefficient for the constitutive term of ENMI-EU at the 95\% confidence level in Model 2. The p-value (.892) for the effect in Model 1 barely fails to reach significance at the $90 \%$ level.
} 
more female MPs would lead the media to increase the diversity of issues as traditional women's issues are integrated into their messages. However, a female leader sends a stronger symbol of the party's interests, focusing only on these issues. Both of these logics found support in the first part of analysis, which showed that the more women a party has in visible positions, the more likely media are to draw greater attention to women's issues, with the effect being clearest for female party leaders.

Altogether the control variables and the models perform relatively well. Parties that hold more seats in their national parliaments increase their expected number of media comments. Parties that address more issues in prior national elections gain no more or less reports on compassion based issues. Accounting for other factors, media reports on compassion based issues are substantially more likely to address conservative parties, perhaps indicating that conservative parties avoid these issues in their manifestos, yet the media reports on them anyways. Parties with self-imposed quotas for gender increase the diversity of issues in their coverage, but has not significant effect on attention to compassion based issues. The existence of quota laws is associated with decreased attention to compassion based issues and issue diversity. This result suggests that adoption of these laws potentially occurs in countries where compassion based issues are traditionally under-represented (Krook and O'Brien 2012). Alternatively, the media may be biased towards female candidates in such contexts and view them as secondary to other candidates (Lühiste and Banducci 2016), and thus pay less attention to the issues they bring to the public sphere. Finally, parties mentioned more often in the media increase the expected number of reports on compassion based issues.

\section{DISCUSSION}

Building on studies of women's representation and issue competition, we argue that parties with more female MPs gain media attention on a wider range of issues as they draw additional attention to traditional women's or compassion based issues. Having a female party leader decreases the diversity as media reports only focus on these topics. Both greater parliamentary party diversity and having a female party leader increase the media's attention to compassion based issues. We demonstrate evidence consistent with our hypotheses from an unlikely case of gender representation and media bias. In particular, we connect data on parties' European Parliamentary election manifestos to media reports prior to European Parliament elections in 1999, 2004 and 2009 in a range of European democracies. Using these data we predict the effect of the percentage female MPs and female party leaders in 
two analyses intended to demonstrate the theory: the media's attention to compassion based issues and the diversity of media attention parties receive.

Like studies of party policy change (Kittilson 2001; Greene and O'Brien 2016, although see Somer-Topcu 2016), the preliminary evidence suggests strong, consistent effects of the presence of female MPs, yet less support for the effects of party leaders. These results, however, are only tentative. More extensive analyses using detailed time series data will identify the causal pathway leading the media to report differently than parties' campaign messages alone would predict. Further analysis will also reveal the contexts in which parties can overcome or potentially even manipulate the media's prejudice by using MP and leader descriptive traits as symbols of the parties' priorities.

The results from the theory and analyses hold clear implications for parties' issue based strategies (Greene 2015; Greene and O'Brien 2016). Assuming that the media moderates the effectiveness of parties' campaign messages, parties seeking to benefit from making specific policy appeals will have to determine whether their messages are consistent or at odds with how media reports will convey them. Parties with more female MPs gain more media attention on issues historically associated with women. A female party leader also shifts the focus of the media's reporting more dramatically than the presence of female MPs. From a more critical perspective, these findings may also be interpreted as evidence of media's reinforcement of traditional gender stereotypes: no matter which ideological or policy positions a female leader holds and emphasizes in the party manifesto, the media will nevertheless associate her party primarily with compassion based issues.

These results also speak to theories of female representation. The presence of women alone lead to real changes in parties' election campaigns (e.g. Kittilson 2008; 2010), but we also add that they shift the way voters receive information about parties through media reports. This is a significant finding in relation to the extent to which women's current descriptive representation can facilitate symbolic representation as well as the future of women in politics. While some past studies found the presence of women candidates to have little effect on women's political trust, efficacy, and engagement (Lawless 2004; Dolan 2006), others show that women in constituencies with viable female candidates are more politically engaged than women residing in electoral districts with only male candidates or non-competitive women candidates (Atkeson 2003). Ultimately, the process encouraging media reports based on descriptive symbols, such as gender, likely determines the conditions in which parties pursue policies substantively representing women and the issues on which governments are held accountable for enacting. Moreover, it is also likely to affect the ways in which parties gender balance their ticket in subsequent elections and affect the party-determined viability of female candidacies (Lühiste 2015). 
Furthermore, these results might add that media reporting allows women's unique policy priorities (e.g. Kittilson 2008, 2010; Greene and O'Brien 2014) in parliament to make their way on to the electoral agenda even when parties exclude them from their campaigns. The presence of women alone may encourage an image of attentiveness to issues through media attention. Visibility, like viability, can lead constituents to feel represented. In turn, a lack of women's presence likely exacerbates media exclusion of social groups and reinforces traditional value systems (Scammel and Semetko 2000). Parties' poor commitment to increasing women's representation leads the media to potentially ignore certain topics that women, in particular, care about. This, however, can have severe implication to women's mass political engagement and efficacy. Ultimately, this discussion suggests a more nuanced perspective for the representation of social group interests based on the symbolic presence of diverse groups. Through media attention to issues, increased presence of diverse groups in prominent roles encourages more inclusive media attention to topics that the traditionally under-represented groups care most about.

Yet, these findings are temporally limited. A skeptical observer might add that recent changes in the European political landscape such as the increased popularity of populists or the further advancement of women leaders in many European democracies might limit our ability to make inferences to ongoing politics. ${ }^{15}$ Anecdotal evidence from current news reports, however, suggest continuity in the ways European media cover political women as well as the issues they are associated with. For example, the current British Prime Minister Theresa May attracts a lot of media attention on her appearance and fashion choices (e.g. the Daily Mail's recent controversy over the 'legs-it' meeting between the PM and the First Minister of Scotland, Nicola Sturgeon), leaving less space for more diverse and substantive issue coverage. Because we have yet to witness a revolution in the way that media cover women in politics we expect that the findings of our study likely remain relevant for contemporary politics. This research calls for theories of media and campaigns that better understand the ways in which media use simple symbols to make strong inferences about party and candidates' characteristics.

\footnotetext{
${ }^{15}$ We find evidence in a working paper on media coverage in the 2014 European Parliament elections in Ireland, the Netherlands, and the United Kingdom using structural topic models that parties with more female MPs receive greater coverage on compassion issues.
} 
Figure1. Distribution of the Effective Number of Media Issues (M-ENI).

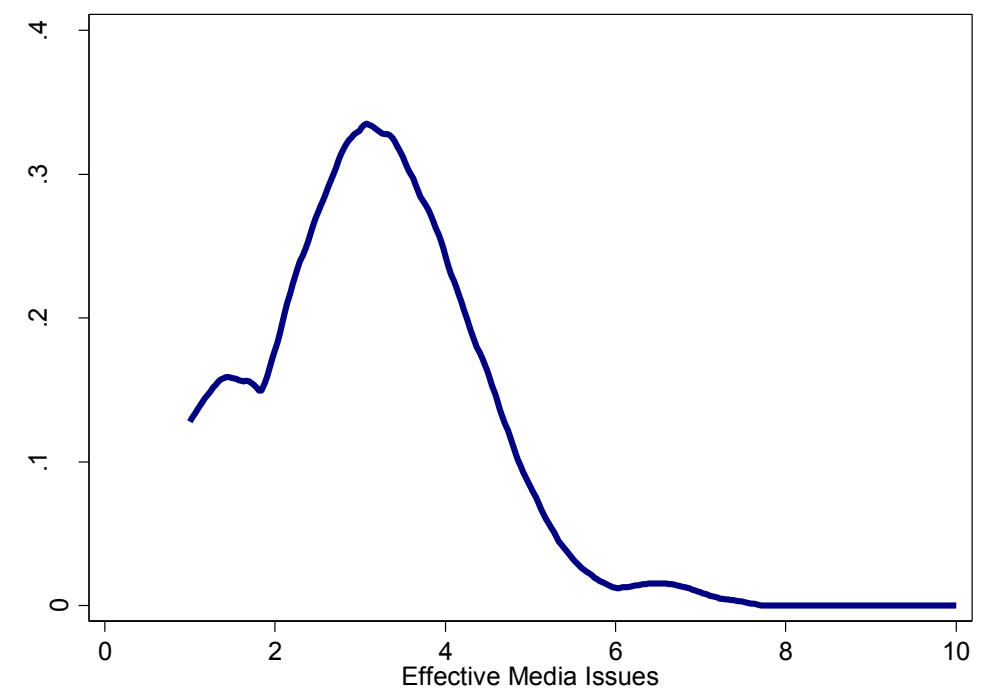

Figure 2. Statements on Women's Issues.

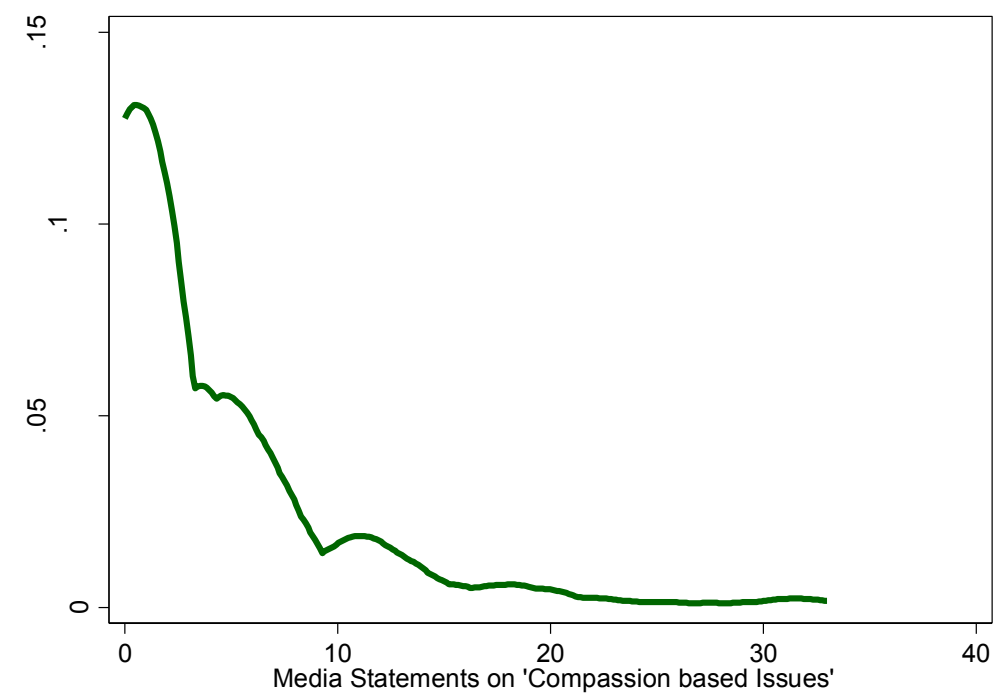


Figure 3. Predicted Effect of Female MPs on the number of media reports. ${ }^{16}$
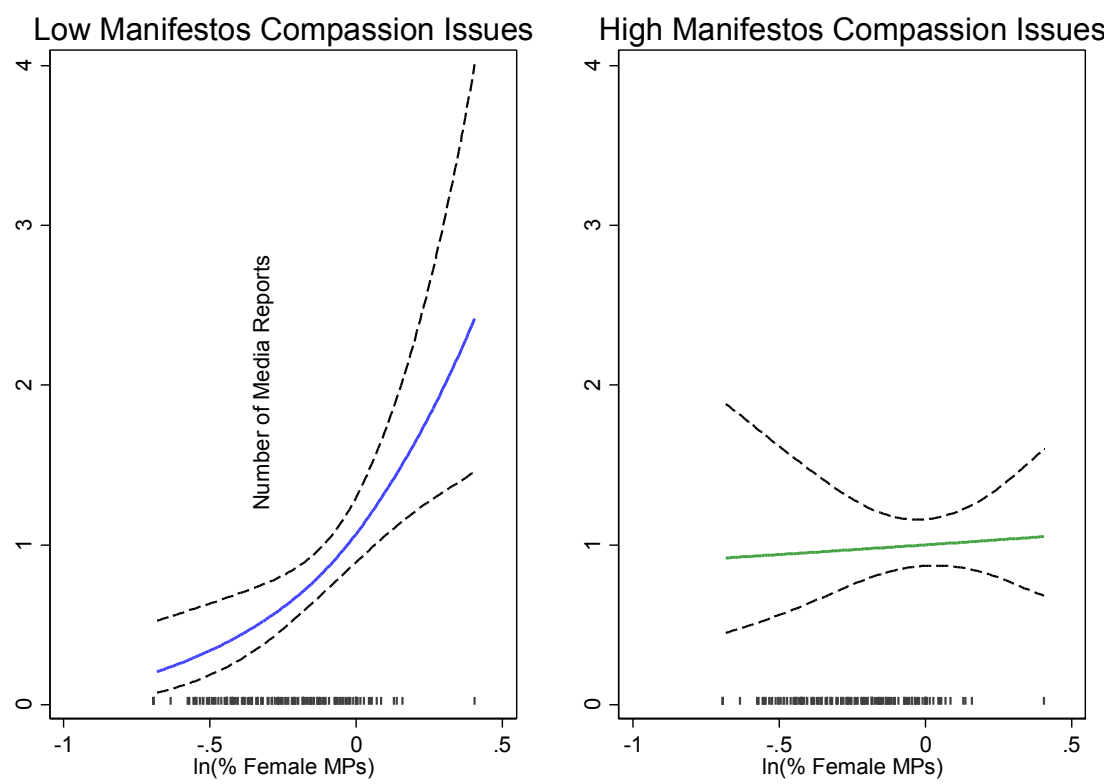

Figure 4. Predicted Effect of a Female Party Leader on the Number of Media Reports.
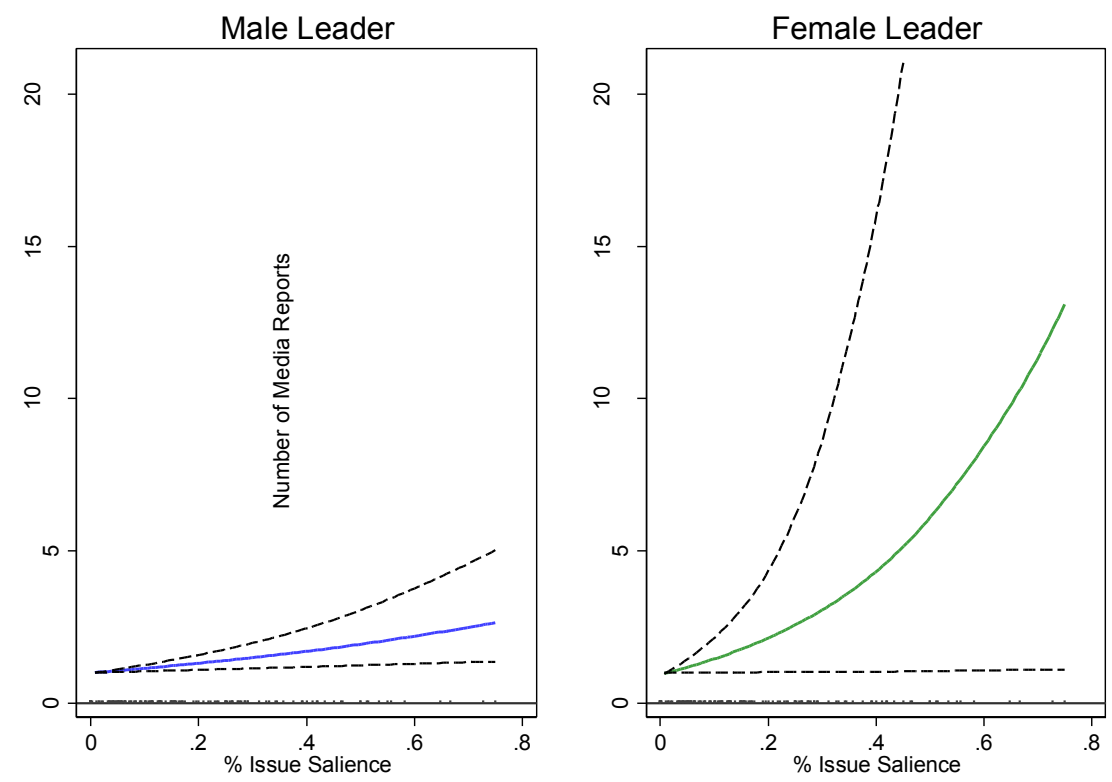

\footnotetext{
${ }^{16}$ Predicted effects in Figure 3 and Figure 4 are constructed using 1000 draws of the variancecovariance matrices based on the results in Model 1 and Model 2 in Table 1 for one standard deviation below and above the mean level of issue salience for compassion based issues. The median marginal effect and 95\% confidence intervals are smoothed using lowess.
} 
Figure 5. Marginal Effect of ENMI-EU on M-ENI. ${ }^{17}$
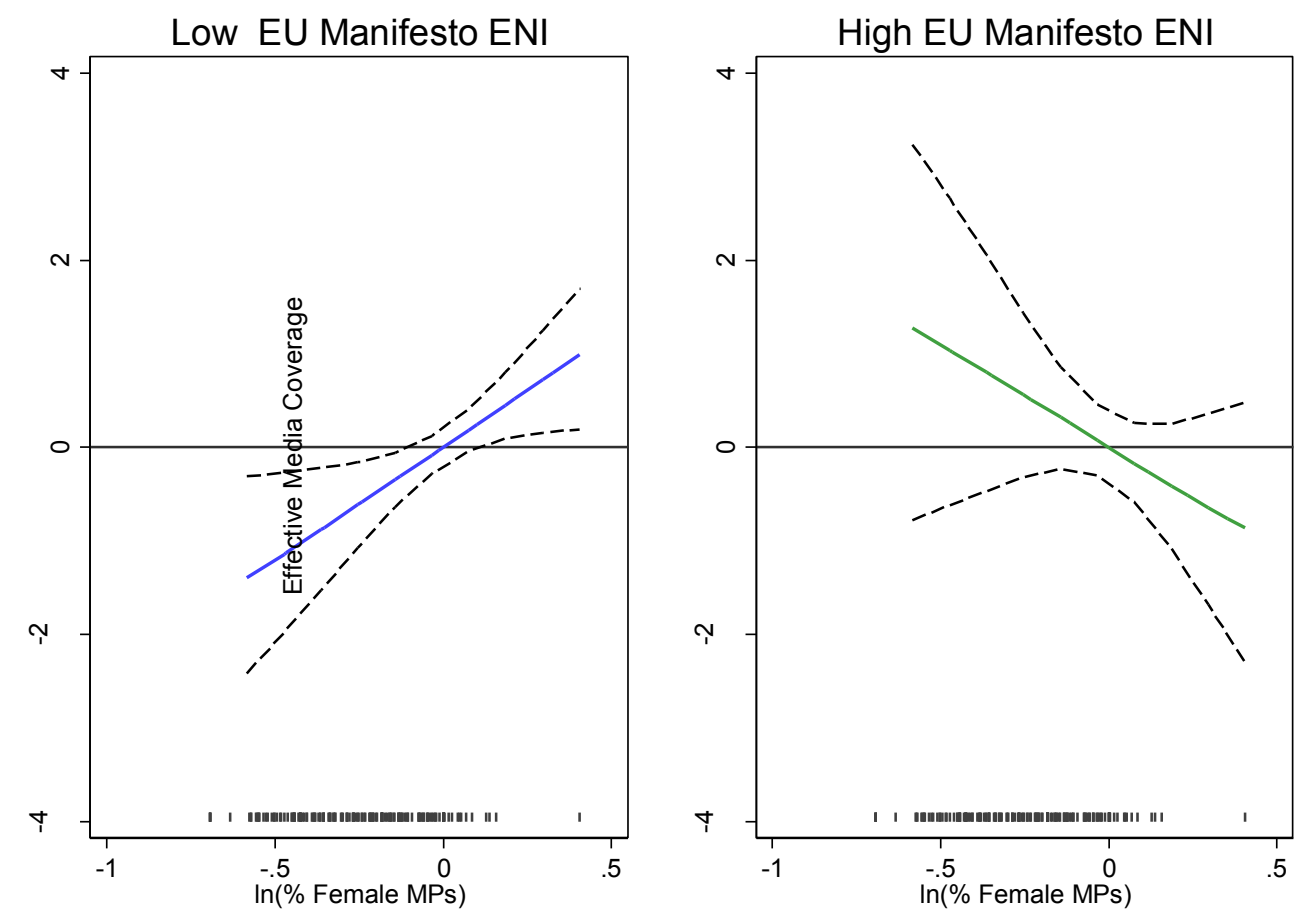

Figure 6. Marginal Effect of a Female Party Leader on M-ENI.

\footnotetext{
17 Marginal effects in Figure 5 and Figure 6 are constructed using 1000 draws of the variancecovariance matrix based on the results in Model 3 and Model 4 in Table 2 for one standard deviation below and above the mean level of ENMI-EU. The median marginal effect and 95\% confidence intervals are smoothed using lowess.
} 


\section{Female Party Leader}

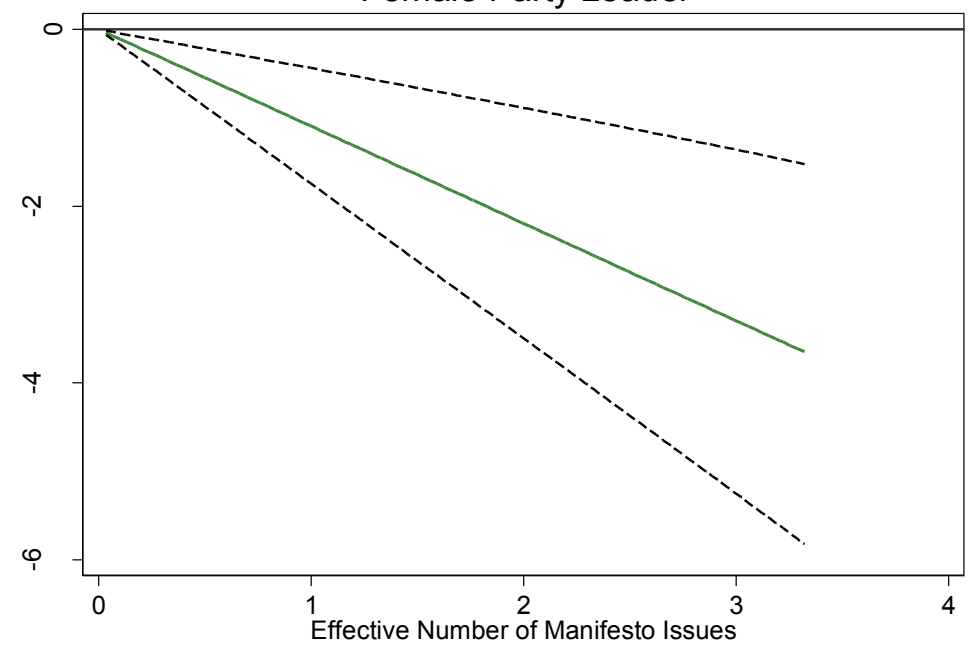


Table 1. Random Effects Negative Binomial Regression Predicting Media Coverage of Compassion Based Issues

\begin{tabular}{|c|c|c|}
\hline & $\begin{array}{c}(1) \\
\text { Simple }\end{array}$ & $\begin{array}{l}(2) \\
\text { Full }\end{array}$ \\
\hline$\%$ Female MPs & $\begin{array}{l}-0.111 \\
(0.707)\end{array}$ & $\begin{array}{c}2.250^{* * *} \\
(0.670)\end{array}$ \\
\hline \% Female MPs X \% & 0.875 & $-6.163^{* *}$ \\
\hline Issue - EU & $(2.374)$ & $(2.368)$ \\
\hline Female Party Leader & $\begin{array}{c}0.235 \\
(0.389)\end{array}$ & $\begin{array}{l}-0.067 \\
(0.354)\end{array}$ \\
\hline \multirow[t]{2}{*}{$\begin{array}{l}\text { Female Party Leader X } \\
\% \text { Issue - EU }\end{array}$} & $-2.816^{+}$ & 2.158 \\
\hline & $(1.699)$ & $(1.776)$ \\
\hline \multirow{2}{*}{$\begin{array}{l}\% \text { Compassion Issue - } \\
\text { EU Manifesto }\end{array}$} & $2.050^{*}$ & -0.250 \\
\hline & $(0.852)$ & $(0.771)$ \\
\hline ENMI - Nat Manifesto & & $\begin{array}{c}0.016 \\
(0.018)\end{array}$ \\
\hline Left-Right position & & $\begin{array}{c}0.715^{* * *} \\
(0.162)\end{array}$ \\
\hline Election & & $0.216^{+}$ \\
\hline $\ln$ (Total Media Reports) & & $\begin{array}{c}(0.123) \\
0.783^{* * *} \\
(0.079)\end{array}$ \\
\hline Party Quota & & $\begin{array}{l}-0.005 \\
(0.005)\end{array}$ \\
\hline Quota Law & & $\begin{array}{c}-0.037^{* *} \\
(0.012)\end{array}$ \\
\hline Constant & $\begin{array}{l}-1.294^{* * *} \\
(0.265) \\
\end{array}$ & $\begin{array}{c}-2.630^{* * * *} \\
(0.682) \\
\end{array}$ \\
\hline \multicolumn{3}{|l|}{$\ln \_r$} \\
\hline Constant & $\begin{array}{c}15.666 \\
(340.856)\end{array}$ & $\begin{array}{c}13.654 \\
(518.834)\end{array}$ \\
\hline \multicolumn{3}{|l|}{$\ln \_s$} \\
\hline Constant & $\begin{array}{c}17.955 \\
(340.856) \\
\end{array}$ & $\begin{array}{c}14.639 \\
(518.836) \\
\end{array}$ \\
\hline AIC & 727.752 & 602.038 \\
\hline $\mathrm{BIC}$ & 752.099 & 644.646 \\
\hline Log-Likelihood & -355.876 & -287.019 \\
\hline Observations & 155 & 155 \\
\hline
\end{tabular}


Table 2. Fixed Effect OLS Models Predicting Effective Number of Media Issues (MENI)

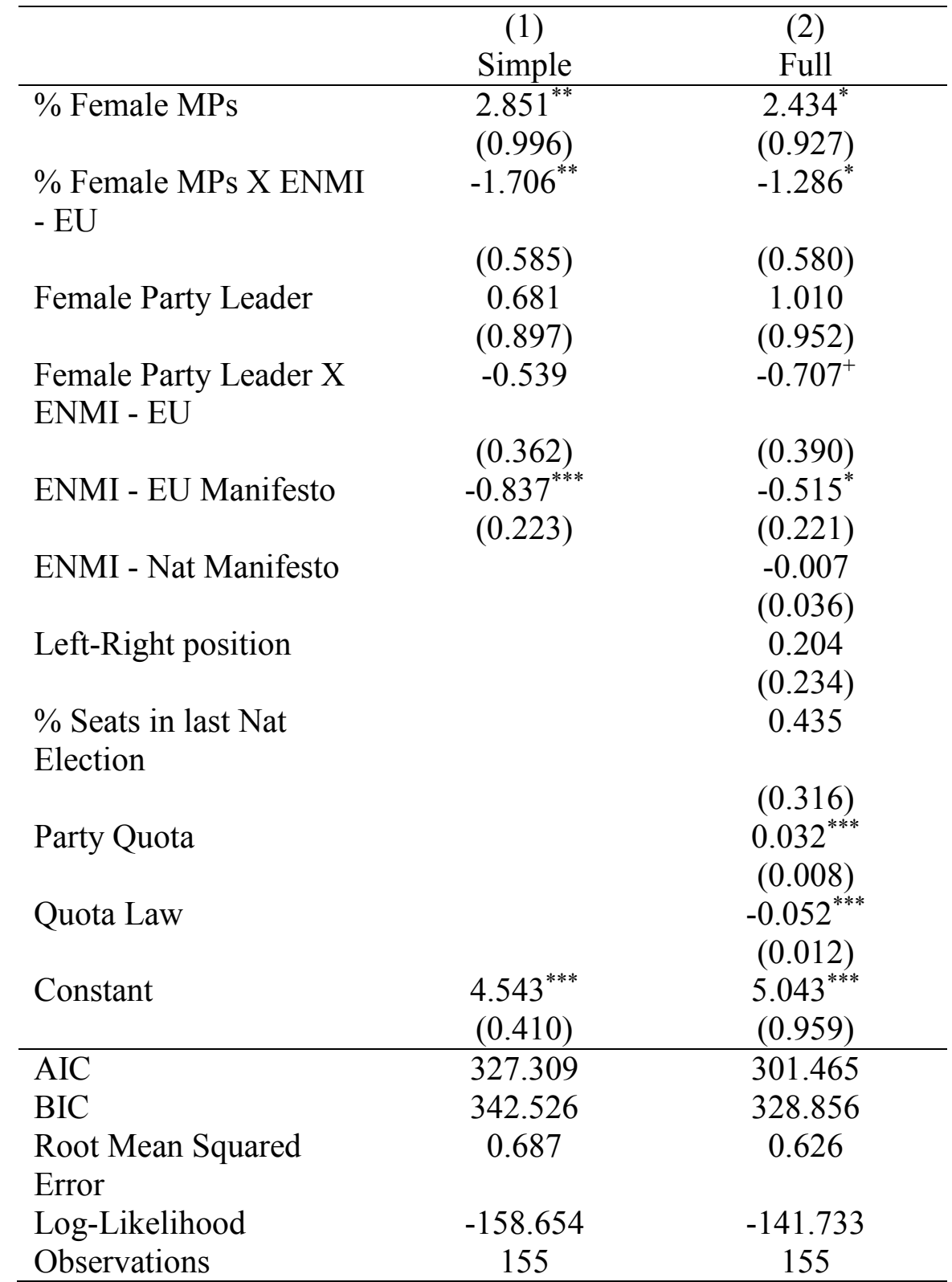

Note: The dependent variable is the Effective Number of Media Issues. Fixed Effects for the party are included. Robust standard errors are presented in the parentheses. All significance tests are two tailed. ${ }^{+} p<0.10,{ }^{*} p<0.05,{ }^{* *} p<0.01,{ }^{* * *} p<0.001$ 


\section{Bibliography}

Altheide, David, and Robert Snow. 1979. "Media logic." Sage Publications.

Atkeson, Lonna Rae. 2003. “Not all cues are created equal: The conditional impact of female candidates on political engagement." Journal of Politics 65(4): 1040-1061.

Atkeson, Lonna Rae, and Timothy Krebs. 2008. “Press coverage of mayoral candidates: The role of gender in news reporting and campaign issue speech." Political Research Quarterly 61 (2): 239-252.

Bäck, Hanna, Marc Debus, and Jochen Müller. 2014. “Who Takes the Parliamentary Floor? The Role of Gender in Speech-making in the Swedish Riksdag." Political Research Quarterly: 1065912914525861.

Banducci, Susan, Heiko Giebler, and Sylvia Kritzinger. 2015. “Knowing More from Less: How the Information Environment Increases Knowledge of Party Positions." British Journal of Political Science: 1-18.

Bartels, Larry. 1996. "Entertainment television items on 1995 pilot study." Report to the National Election Studies Board of Overseers.

Bélanger, Éric, and Bonnie M. Meguid. 2008. "Issue salience, issue ownership, and issue-based vote choice." Electoral Studies 27(3): 477-491.

Bevan, Shaun, and Zachary Greene. 2016. "Looking for the party? The effects of partisan change on issue attention in UK Acts of Parliament." European Political Science Review 8 (1) 49-72.

Bevan, Shaun, and Zachary Greene. 2017. “Cross-National partisan Effects on Agenda Stability." Journal of European Public Policy, DOI: 10.1080/13501763.2016.1268641.

Boydstun, Amber, Shaun Bevan, and Herschel Thomas. 2014. "The Importance of Attention Diversity and How to Measure It." Policy Studies Journal 42(2): 173196.

Braun, Daniela; Mikhaylov, Slava, and Hermann Schmitt (2010), EES (2009) Manifesto Study Documentation Advance Release (user beware/ pre-release B), 22/07/2010, www.piredeu.eu. 
Burrell, Barbara. 1994. A Woman's Place is in the House. Ann Arbor: University of Michigan Press.

Bystrom, Dianne G., Terry A. Robertson, and Mary Christine Banwart. 2001. "Framing the Fight An Analysis of Media Coverage of Female and Male Candidates in Primary Races for Governor and US Senate in 2000." American Behavioral Scientist 44(12): 1999-2013.

Conroy, Meredith, Sarah Oliver, Ian Breckenridge-Jackson, and Caroline Heldman. 2015. "From Ferraro to Palin: sexism in coverage of vice presidential candidates in old and new media." Politics, Groups, and Identities 3(4): 573-591.

Dabelko, Kirsten La Cour, and Paul S. Herrnson. 1997. “Women's and Men's Campaigns for the US House of Representatives." Political Research Quarterly 50(1): 121-135.

Dodson, Debra L. 2006. The impact of women in Congress. Oxford University Press, USA.

Dolan, Julie. 1998. “Support for women's interests in the 103rd Congress: The distinct impact of congressional women." Women $\mathcal{E}$ Politics 18(4): 81-94.

Dolan, Kathleen. 2006. "Symbolic mobilization? The impact of candidate sex in American elections." American Politics Research 34(6): 687-704.

Dunaway, Johanna, Regina G. Lawrence, Melody Rose, and Christopher R. Weber. 2013. "Traits versus Issues How Female Candidates Shape Coverage of Senate and Gubernatorial Races." Political Research Quarterly 66(3): 715-726.

EES (2009), European Parliament Election Study 2009, Manifesto Study Data, Advance Release (user beware/ pre-release B), 22/07/2010, (www.piredeu.eu).

Eilders, Christiane. 1997. The impact of editorial content on the political agenda in Germany: theoretical assumptions and open questions regarding a neglected subject in mass communication research. WZB Discussion Paper.

Evans, Geoffrey, and Robert Andersen. 2005. "The impact of party leaders: How Blair lost Labour votes." Parliamentary Affairs 58(4): 818-836. 
Farrell, David, and Paul Webb. 2006. "Political parties as campaign organizations."

Fox, Richard Logan. 1997. 2 Gender dynamics in congressional elections. Sage.

Freedman, Paul, Michael Franz, and Kenneth Goldstein. 2004. “Campaign advertising and democratic citizenship." American Journal of Political Science 48(4): 723-741.

Geys, Benny. 2012. "Success and failure in electoral competition: Selective issue emphasis under incomplete issue ownership." Electoral Studies 31(2): 406-412.

Gidengil, Elisabeth, and Joanna Everitt. 2000. "Filtering the female: Television news coverage of the 1993 Canadian leaders' debates." Women \& Politics 21(4): 105131.

Goldenberg, Edie N., and Michael W. Traugott. 1987. “Mass media in US congressional elections." Legislative Studies Quarterly: 317-339.

Gordon, Stacy, and Gary Segura. 1997. "Cross-National Variation in the Political Sophistication of Individuals: Capability or Choice?" The Journal of Politics 59(01): 126-147.

Greene, Zachary. 2015. "Competing on the issues: How experience in government and economic conditions influence the scope of parties' policy messages." Party Politics 22 (6): 809-822.

Greene, Zachary, and Diana Z. O’Brien. 2016. “Diverse parties, diverse agendas? Female politicians and the parliamentary party's role in platform formation." European Journal of Political Research 55 (3): 435-453.

Greene, Zachary, and Maarja Lühiste. 2017. "Gender and Media Coverage in the 2014 European Elections.“ Working Paper. Available at: http://www.zacgreene.com/research.html.

Hallin, Daniel, and Paolo Mancini. 2004. Comparing media systems: Three models of media and politics. Cambridge University Press. 
Haselmayer, Martin, Thomas Meyer, and Markus Wagner. 2015. "Who Gets Into the Papers? Media Attention to Party Communication in Election Campaigns." Presented at the Midwest Political Science Association (June 19), Chicago, IL.

Hayes, Danny. 2008. “Party reputations, journalistic expectations: How issue ownership influences election news." Political Communication 25(4): 377-400.

Heldman, Caroline, Susan J. Carroll, and Stephanie Olson. 2005. “'She brought only a skirt': print media coverage of Elizabeth Dole's bid for the Republican presidential nomination." Political Communication 22(3): 315-335.

Helfer, Luzia, and Peter Van Aelst. 2016. “What Makes Party Messages Fit for Reporting? An Experimental Study of Journalistic News Selection." Political Communication 33(1): 59-77.

Hellwig, Timothy. 2012. "Constructing Accountability Party Position Taking and Economic Voting." Comparative Political Studies 45(1): 91-118.

Hopmann, David, Christian Elmelund-Præstekær, Erik Albæk, Rens Vliegenthart, et al. 2012. "Party media agenda-setting: How parties influence election news coverage." Party Politics 18(2): 173-191.

Huddy, Leonie, and Nayda Terkildsen. 1993. "Gender stereotypes and the perception of male and female candidates." American Journal of Political Science: 119-147.

Iyengar, Shanto, and Donald R. Kinder. 1987. "News that matters: Agenda-setting and priming in a television age." News that Matters: Agenda-Setting and Priming in a Television Age.

Jost, Lou. 2006. “Entropy and diversity.” Oikos 113(2): 363-375.

Kahn, Kim. 1994. "Does gender make a difference? An experimental examination of sex stereotypes and press patterns in statewide campaigns." American Journal of Political Science: 162-195.

Kahn, Kim. 1996. The political consequences of being a woman: How stereotypes influence the conduct and consequences of political campaigns. Columbia University Press. 
King, David, and Richard Matland. 2003. "Sex and the grand old party an experimental investigation of the effect of candidate sex on support for a republican candidate." American Politics Research 31(6): 595-612.

Kittilson, Miki Caul. 2008. "Representing women: The adoption of family leave in comparative perspective." The Journal of Politics 70(02): 323-334.

Kittilson, Miki Caul. 2011. "Women, parties and platforms in post-industrial democracies." Party Politics 17(1): 66-92.

Kittilson, Miki Caul, and Kim Fridkin. 2008. "Gender, candidate portrayals and election campaigns: A comparative perspective." Politics $\mathcal{E}$ Gender 4(3): 371-92.

Kleinnijenhuis, Jan, and Paul Pennings. 2001. “Measurement of party positions on the basis of party programmes, media coverage and voter perceptions." Estimating the policy positions of political actors: 162.

Koch, Jeffrey. 2002. "Gender stereotypes and citizens' impressions of House candidates' ideological orientations." American Journal of Political Science: 453462.

Kölln, Ann-Kristin. 2014. "Party membership in Europe Testing party-level explanations of decline." Party Politics: 1354068814550432.

Kostadinova, Petia. 2015. "Party pledges in the news: Which election promises do the media report?" Party Politics FirstView:1-10.

Krook, Mona, and Diana Z. O'Brien. 2012. “All the President's Men? The Appointment of Female Cabinet Ministers Worldwide." The Journal of Politics 74(3): 840-855.

Lawless, Jennifer L. 2004. “Women, war, and winning elections: Gender stereotyping in the post-September 11th era." Political Research Quarterly 57(3): 479-490.

Lowe, Will, Kenneth Benoit, Slava Mikhaylov, and Michael Laver. 2011. "Scaling policy preferences from coded political texts." Legislative Studies Quarterly 36(1): 123-155.

Luskin, Robert. 1990. "Explaining political sophistication." Political Behavior 12(4): 331-361. 
Luhiste, Maarja. 2015. "Party gatekeepers' support for viable female candidacy in PRlist systems." Politics \& Gender 11(1), 89-116.

Lühiste, Maarja, and Susan Banducci. 2016. “Invisible women? Comparing candidates' news coverage in Europe." Politics E Gender 12(2), 223-253.

Lühiste, Maarja, and Meryl Kenny. 2016. "Pathways to power: Women's representation in the 2014 European Parliament Elections." European Journal of Political Research 55(3), 626-641.

McDermott, Monika L. 1997. “Voting cues in low-information elections: Candidate gender as a social information variable in contemporary United States elections." American Journal of Political Science: 270-283.

Meeks, Lindsey. 2012. "Is she 'man enough'? Women candidates, executive political offices, and news coverage." Journal of Communication 62(1): 175-193.

Newton, Kenneth. 1999. "Mass media effects: mobilization or media malaise?" British Journal of Political Science 29(04): 577-599.

Norris, Pippa. 2000. A virtuous circle: Political communications in postindustrial societies. Cambridge University Press.

O’Brien, Diana Z., Matthew Mendez, Jordan Peterson, and Jihyun Shin. 2015. "Letting Down the Ladder or Shutting the Door: Female Prime Ministers, Party Leaders, and Cabinet Ministers." Politics \& Gender 11(4): 689-717.

O'Brien, Diana Z. 2015. "Rising to the Top: Gender, Political Performance, and Party Leadership in Parliamentary Democracies." American Journal of Political Science 59(4): 1022-1039.

Plutzer, Eric, and John Zipp. 1996. “Identity politics, partisanship, and voting for women candidates." Public Opinion Quarterly 60(1): 30-57.

Protess, David et al. 1987. “The impact of investigative reporting on public opinion and policymaking targeting toxic waste." Public Opinion Quarterly 51(2): 166185. 
Robinson, Michael . 1976. "Public Affairs Television and the Growth of Political Malaise: The Case of 'The Selling of the Pentagon'." American political science review 70(02): 409-432.

Ross, Karen, Elizabeth Evans, Lisa Harrison, Mary Shears, et al. 2013. “The Gender of News and News of Gender A Study of Sex, Politics, and Press Coverage of the 2010 British General Election." The International Journal of Press/Politics 18(1): 3-20.

Santen, Rosa van, Luzia Helfer, and Peter van Aelst. 2013. “When politics becomes news: An analysis of parliamentary questions and press coverage in three West European countries." Acta Politica 50 (1): 45-63.

Schoenbach, Klaus. 1991. “Agenda-setting effects of print and television in West Germany." Agenda-setting. Readings on media, public opinion and policymaking: 127-129.

Schuck, Andreas, Georgios Xezonakis, Matthijs Elenbaas, Susan Banducci, et al. 2011. "Party contestation and Europe on the news agenda: The 2009 European Parliamentary Elections." Electoral Studies 30(1): 41-52.

Semetko, Holli, Jay Blumler, Michael Gurevitch, David Weaver, et al. 2013. The formation of campaign agendas: A comparative analysis of party and media roles in recent American and British elections. Routledge.

Somer-Topcu, Zeynep. 2016. "Agree or disagree: How do party leader changes affect the distribution of voters' perceptions." Party Politics: 1354068816655568.

Swers, Michele. 2002. The difference women make: The policy impact of women in Congress. University of Chicago Press.

Thesen, Gunnar. 2013. "When good news is scarce and bad news is good: Government responsibilities and opposition possibilities in political agendasetting." European Journal of Political Research 52(3): 364-389.

Traudt, Paul. 2005. Media, audiences, effects. Boston: Pearson.

Vavreck, Lynn. 2009. The Message Matters: The Economy and Presidential Campaigns. Princeton University Press. 
Volkens, Andrea, Pola Lehmann, Theres Matthieß, Nicolas Merz, Sven Regel, Annika Werner. 2015. The Manifesto Data Collection. Manifesto Project (MRG/CMP/MARPOR). Version 2015a. Berlin: Wissenschaftszentrum Berlin für Sozialforschung (WZB)

Walgrave, Stefaan, and Knut De Swert. 2004. “The making of the (issues of the) Vlaams Blok." Political Communication 21(4): 479-500.

Walgrave, Stefaan, Stuart Soroka, and Michiel Nuytemans. 2007. “The Mass Mediaэs Political Agenda-Setting Power: A Longitudinal Analysis of Media, Parliament, and Government in Belgium (1993 to 2000)." Comparative Political Studies.

Weaver, Paul. 1981. "TV news and newspaper news." Understanding television: 27793.

West, Darrell. 2001. The rise and fall of the media establishment. Bedford/St. Martin's Boston.

Williams, Bruce, and Michael X. Delli Carpini. 2011. After broadcast news: Media regimes, democracy, and the new information environment. Cambridge University Press.

Williams, Laron, Katsunori Seki, and Guy Whitten. 2016. "You've Got Some Explaining To Do The Influence of Economic Conditions and Spatial Competition on Party Strategy." Political Science Research and Methods 4(1): 47-63.

Woodall, Gina Serignese, and Kim Fridkin. 2003. "Shaping women's chances: Stereotypes and the media." Anticipating Madam President: 69-86.

Zaller, John. 1999. “A theory of media politics.” Manuscript, October 24(1999): 61-101. 


\section{Appendix}

Compassion issues

We develop a measure of compassion based issues from the media based on the European Election Study's categorizations. We generate a count of the number of times the media references issues labelled as women's issues, education, social justice groups or minority groups in connection with a party using the EES Media Study issue categories. We show the exact classifications in Table A1 below. The four categories that we sum to measure compassion based issues are in grey.

We construct our measure from the Euromanifestos by finding the sum of the percentage of statements related to "Welfare State Expansion" (All codes classified under 504), "Education" (codes under 506), and “Underprivileged Minority Groups" (codes under 705).

Table A1. EES Media Study Issue Codes.

\begin{tabular}{|l|l|}
\hline $\begin{array}{l}\text { EES Media Studies issue categories } \\
\text { (PIREDEU Longitudinal Data 1999-2009) }\end{array}$ & Issue category \\
\hline $\begin{array}{l}3-\text { Politics in general / Characteristics of } \\
\text { democracy } \\
2-\text { Other elections } \\
20-\text { Party politics }\end{array}$ & $1-$ Democracy \\
\hline $4-$ Federalism / administrative efficiency & $2-$ Federalism \\
\hline $\begin{array}{l}5-\text { Law and order / corruption / domestic } \\
\text { security }\end{array}$ & $3-$ Law and order \\
\hline $\begin{array}{l}7-\text { EU integration / EU enlargement } \\
1-\text { EU elections } \\
6-\text { EU politics / EU institutions / competences } \\
\text { of the EU institutions }\end{array}$ & $4-$ EU politics \\
\hline $\begin{array}{l}8-\text { Foreign affairs and defence (NATO, peace, } \\
\text { war) }\end{array}$ & $5-$ Foreign affairs and defence \\
\hline $\begin{array}{l}9-\text { Economic structure / policies / goals / } \\
\text { conditions / fiscal policy / Euro }\end{array}$ & 6 - Economy \\
\hline
\end{tabular}




\begin{tabular}{|l|l|}
\hline $\begin{array}{l}\text { EES Media Studies issue categories } \\
\text { (PIREDEU Longitudinal Data 1999-2009) }\end{array}$ & Issue category \\
\hline $18-$ Transportation & \\
\hline $10-$ Environment / climate change / energy & $7-$ Environment \\
\hline $\begin{array}{l}11-\text { Social policy / social welfare } \\
12-\text { Health care / health policy }\end{array}$ & $8-$ Social policy and welfare \\
\hline $\begin{array}{l}13-\text { Immigration / multiculturalism / } \\
\text { nationalism }\end{array}$ & $9-$ Immigration \\
\hline $\begin{array}{l}14-\text { Minority groups and policies (other than } \\
\text { ethnic) }\end{array}$ & $10-$ Minority policies \\
\hline \begin{tabular}{l}
$15-$ Women's issues / gender equality \\
\hline $16-$ Agriculture / food safety
\end{tabular} & $\begin{array}{l}11-\text { Women's issues and gender } \\
\text { equality }\end{array}$ \\
\hline 17 - Education & $12-$ Agriculture \\
\hline $19-$ Culture / history / religion / human interest & $13-$ Education \\
\hline $\begin{array}{l}21-\text { Media and communication } \\
22-\text { Other topics / other policy areas }\end{array}$ & $15-$ Other issues \\
\hline
\end{tabular}

Issue diversity

We construct measures of issue diversity in the media and in parties' manifestos following Jost (2006; Greene 2015). In particular, we transform measures of media attention and manifesto issue entropy (Shannon's H) to measures of diversity following the equation below. We first find the percentage, $p$, of attention to each issue, $i$, in the media dataset (see categories in Table A1) or the European and national manifestos. We identify issues within the media dataset based on the categories identified by the European Election Study. To generate the relative salience to each category, we divided the count of references to each issue by the total number of media references to the party to find the percentage of total references. We undertake an additional step using the Euromanifestos by combining references to the same topic regardless of their directionality or whether they refer to the EU or national level politics; this results in a total of 44 issues (and a potential max diversity of the same number). For the national level control variable, we follow the exact process outlined by Greene (2015).

Using these issue categories for each measure, we then find the negative sum of that percentage multiplied by the natural log of the percentage (we replace the value as equal to zero when the issue is not included at all). Finally, we exponentiate Shannon's entropy to convert it to a measure of diversity (Greene 2015; Greene and O'Brien 2016; van Heck 2016). 


\begin{tabular}{|c|c|}
\hline Shannon's $H=-\sum_{i=1}^{42} p_{i} \ln \left(p_{i}\right)$ & (1) \\
\hline Effective Number of Issues $\left.=\exp (\text { Shannon's } H)^{\prime}\right)$ & (2) \\
\hline
\end{tabular}

